\title{
Frequency of chondrocalcinosis of the knees and avascular necrosis of the femoral heads in gout: a controlled study
}

\author{
A. STOCKMAN, L. G. DARLington, AND J. T. SCOTT \\ From the Charing Cross Hospital and Kennedy Institute of Rheumatology, London
}

SUMMARY An association between urate gout and chondrocalcinosis has been suggested in several studies, but the situation remains ill-defined because of lack of appropriate controls, small numbers of patients studied, or retrospective investigation. An association has also been claimed between gout and avascular necrosis of the femoral head. 138 patients with gout and 142 non-gouty control subjects were carefully matched for age and $x$-rays were taken of the knees and pelvis. Chondrocalcinosis of the knees was detected in 8 patients with gout $(5.8 \%)$, no cases being found in the control group. The difference is significant $(\mathrm{P}<0 \cdot 025)$. Deposits were linear or irregular. Six of the 8 patients gave a history of acute synovitis of the knees; fluid had been aspirated in 2 of them, urate crystals being found in one and no crystals in the other. Six of the 8 patients showed evidence of chondrocalcinosis elsewhere. No association was apparent between chondrocalcinosis and the presence of tophaceous deposits or renal impairment, though the duration of gout appeared to be longer in the patients with chondrocalcinosis than in the other gout patients and osteoarthrosis of the knees commoner. There was no evidence of other metabolic disorders commonly associated with chondrocalcinosis. No cases of avascular necrosis of the femoral head were found.

Despite considerable research into chondrocalcinosis in recent years its pathogenesis remains obscure. An association has been reported with various metabolic disorders such as hyperparathyroidism (McCarty, 1972), haemochromatosis (Dymock et al., 1970), and gout (Dodds and Steinbach, 1966). The association between gout and chondrocalcinosis remains ill defined because of the lack of appropriate controls, small numbers of patients, or retrospective study (Dodds and Steinbach, 1966; Good and Rapp, 1967).

In studying 65 patients with 'idiopathic' avascular necrosis of femoral heads McCollum et al. (1967) found 13 patients with gout, urate crystals being demonstrated in synovial membrane from the hip in 6 of them. Serre et al. (1963) studied hips in 150 patients with gout and found 3 with non-traumatic avascular necrosis of the femoral head. In contrast Rotes Querol and Muno Gomez (1965) found no cases of avascular necrosis in 370 patients with gout.

Accepted for publication 23 February 1979

Correspondence to Dr J. T. Scott, Kennedy Institute of Rheumatology, Bute Gardens, London W6 7DW.
To obtain further information on these points we have conducted a radiological survey of a group of patients with gout and a group of non-gouty control subjects.

\section{Patients and methods}

136 male and 2 female patients with gout and 142 male non-gouty controls were studied. The gout patients were drawn without selection from the Charing Cross Hospital Gout Clinic. All of them had been diagnosed as gout by acceptable clinical criteria: all were hyperuricaemic (or had been before treatment was begun) and had experienced acute episodes of arthritis which had taken the form of typical podagra in 110 of them. Twenty-three had tophi, and urate crystals had been identified from synovial fluid in seven.

The controls were volunteers, carefully matched for age, who were also attending Charing Cross Hospital. There were 130 outpatients, 40 of whom were having radiotherapy for malignant skin lesions and 90 of whom were attending a fracture clinic for treatment of traumatic fractures and abrasions. 


\section{Stockman, Darlington, Scott}

Twelve inpatients with acute medical conditions made up the rest of the control group. These control subjects were questioned as to a history of gouty arthritis; only 1 of them gave such a history; $x$-rays were normal.

To detect chondrocalcinosis and avascular necrosis standard anteroposterior films of the knees and pelvis were taken, radiographs of the knees alone being expected to detect $89-99 \%$ of patients with articular chondrocalcinosis (Ellman and Levin, 1975; Resnick et al., 1977). The films from both groups were mixed and read 'blind' by all 3 authors. They were also graded for severity of osteoarthrosis (Kellgren and Lawrence, 1957).

Plasma uric acid was estimated an enzymatic method in all of the subjects. In those in whom chondrocalcinosis was found serum calcium, phos-

Table 1 Details of gout and control patients

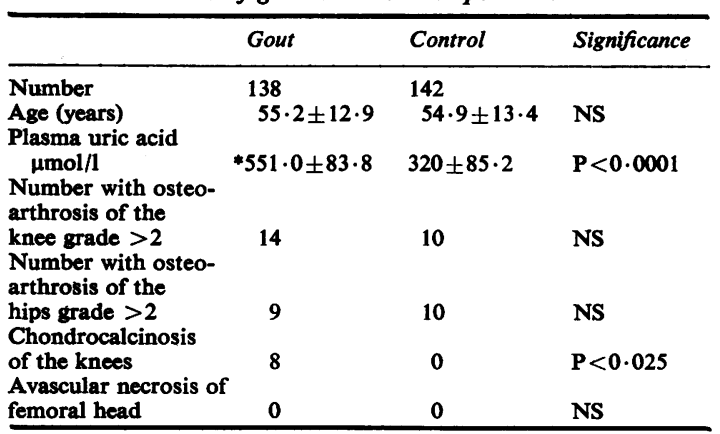

* Pretreatment level. phate, alkaline phosphatase, and iron were estimated, and the wrists were $x$-rayed.

\section{Results}

Details of the gouty and the control groups are shown in Table 1. Attention is drawn to the very close age matching of the 2 groups, together with the fact that there was no significant difference in the prevalence of osteoarthrosis.

Chondrocalcinosis of the knees was detected in 8 patients with gout, a prevalence of $5 \cdot 8 \%$. No cases were found in the control group. This difference is significant $\left(\mathrm{P}<0.025, \chi^{2}\right.$ test with Yates's correction; $P<0.01$, Fisher's exact probability test).

Table 2 shows further details of the 8 gout patients with chondrocalcinosis of the knees. Six of them gave a history of symptoms involving the knees, mainly in the form of acute synovitis, sometimes recurrent. In only 2 of them, however, had the opportunity arisen of aspiring synovial fluid, urate crystals being found in one and no crystals in the other. Thus the cause of the synovitis in the knees (urate or pyrophosphate) in most of themremains unknown, though there is little doubt that all had urate gout involving other joints.

In 5 of the 8 patients the deposits in the knee joints appeared linear on radiological examination (Fig. 1) and involved both knees in 4 of them. One other patient showed both linear and irregular deposits, and the other 2 patients showed irregular deposits only (Fig. 2). In all of them the appearance of

Table 2 Details of 8 gout patients with chondrocalcinosis of knees

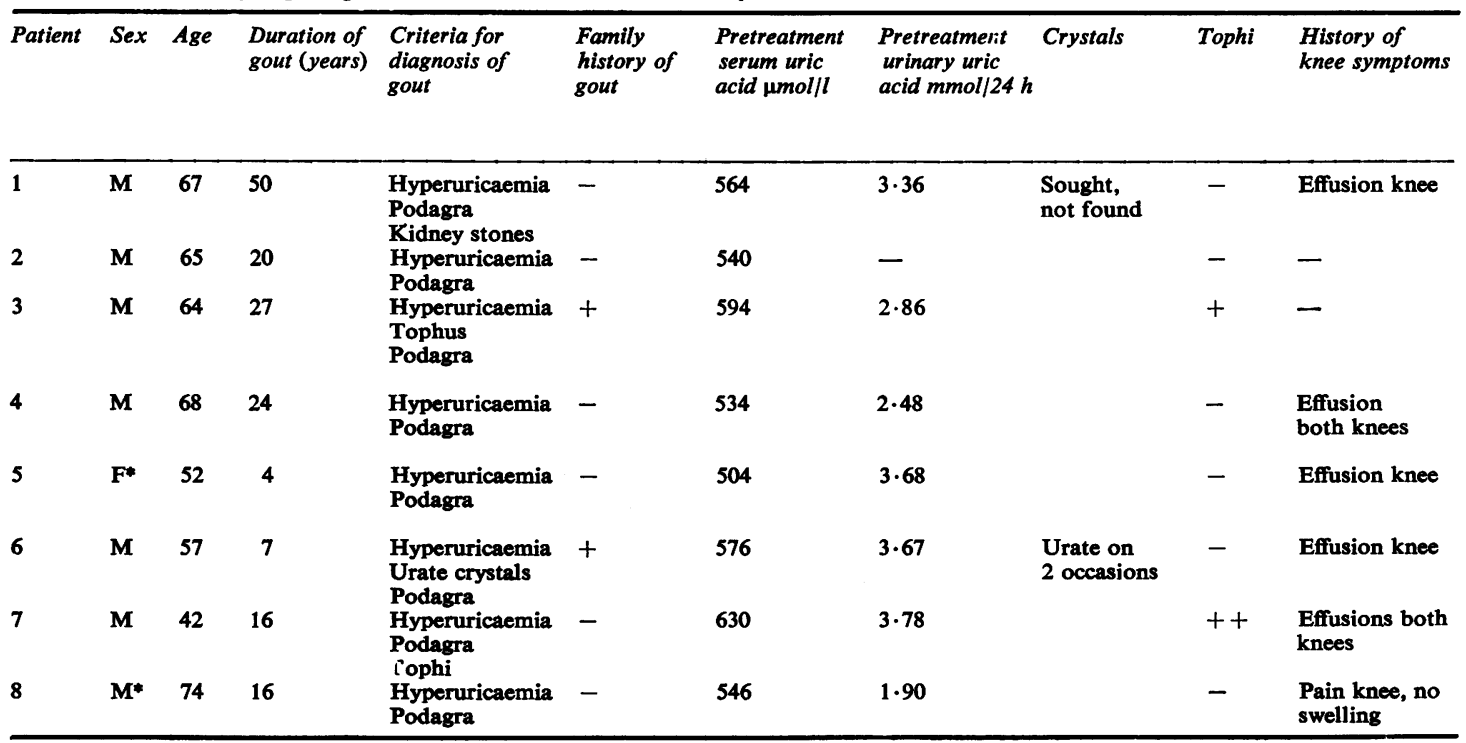

* West Indian. 

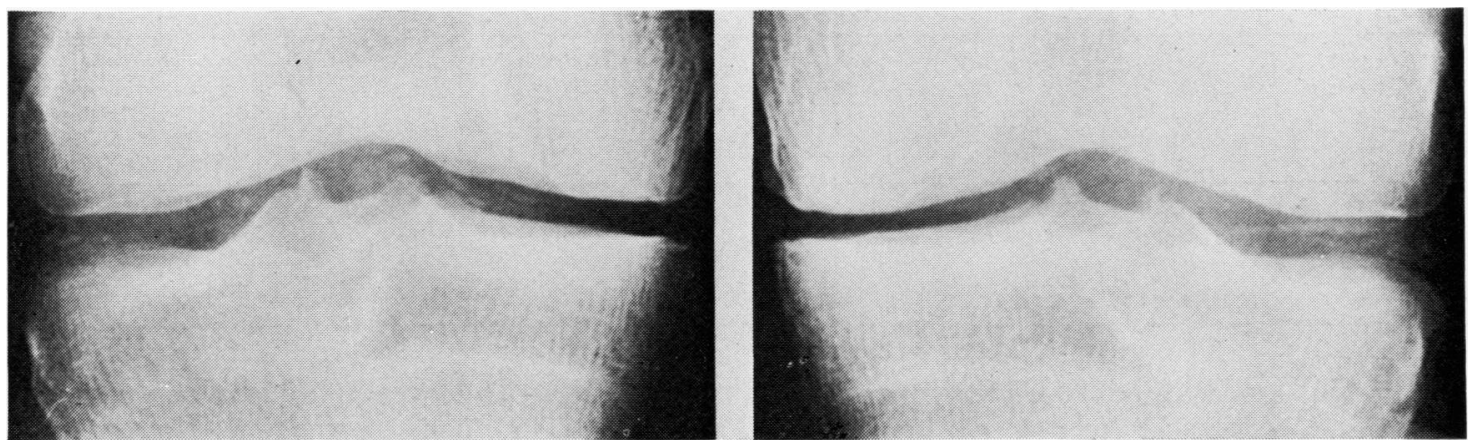

Fig. 1 Linear calcification (case 1)
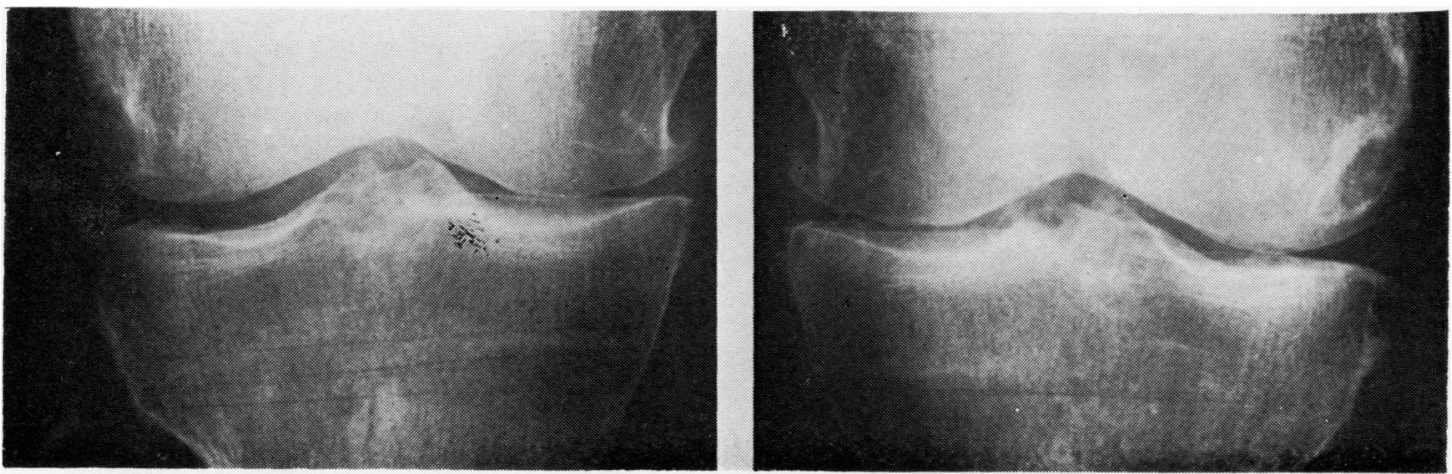

Fig. 2 Irregular calcification (case 7)

\begin{tabular}{|c|c|c|c|c|c|c|c|c|c|c|c|c|c|}
\hline \multirow{2}{*}{$\begin{array}{l}\text { Osteo- } \\
\text { arth- } \\
\text { rosis } \\
\text { of knee } \\
\text { grade) }\end{array}$} & \multicolumn{4}{|c|}{ Chandrocalcinosis of knee } & \multicolumn{3}{|c|}{ Chondrocalcinosis } & \multirow{2}{*}{$\begin{array}{l}\text { Creatinine } \\
\text {-clearance } \\
(\mathrm{ml} / \mathrm{min})\end{array}$} & \multirow{2}{*}{$\begin{array}{l}\text { Serum } \\
\text { calcium } \\
(\mathrm{mmol} / \mathrm{l})\end{array}$} & \multirow{2}{*}{$\begin{array}{l}\text { Serum } \\
\text { phosphate } \\
\text { (mmol/l) }\end{array}$} & \multirow{2}{*}{$\begin{array}{l}\text { Alkaline } \\
\text { phospha- } \\
\text { tase } \\
(K=A \text { unit }\end{array}$} & \multirow{2}{*}{$\begin{array}{l}F e \\
(\mu \mathrm{mol} / \mathrm{l})\end{array}$} & \multirow{2}{*}{$\begin{array}{l}\text { Other } \\
\text { illnesses }\end{array}$} \\
\hline & $\begin{array}{l}\text { Right } \\
\text { Lateral }\end{array}$ & Medial & $\begin{array}{l}\text { Left } \\
\text { Medial }\end{array}$ & Lateral & Wrists & $\begin{array}{l}\text { Pubic } \\
\text { symphy- } \\
\text { sis }\end{array}$ & Hip & & & & & & \\
\hline 2 & Linear & Linear & 0 & Linear & 0 & + & + & 80 & $2 \cdot 46$ & 0.8 & 12 & 28 & Nil \\
\hline 1 & 0 & 0 & Linear & 0 & 0 & + & $\mathbf{0}$ & 95 & $2 \cdot 44$ & $1 \cdot 0$ & 11 & 15 & Nil \\
\hline 0 & Line.ar & Linear & Linear & 0 & + & 0 & 0 & $\begin{array}{l}\text { Plasma } \\
\text { creatinine } \\
165 \mu \mathrm{mol} / 1\end{array}$ & $2 \cdot 45$ & $1 \cdot 1$ & 9 & 17 & $\begin{array}{l}\text { Interstitial } \\
\text { Nephritis } \\
\text { Hypertension } \\
\text { Duodenal ulcer }\end{array}$ \\
\hline 2 & Linear & Linear & 0 & Linear & $\bullet+$ & 0 & + & 84 & $2 \cdot 45$ & - & 5 & 33 & $\begin{array}{l}\text { Left below } \\
\text { knee amputat- } \\
\text { ion } 1968\end{array}$ \\
\hline 1 & Linear & Linear & 0 & Linear & 0 & + & + & 110 & $2 \cdot 53$ & $1 \cdot 3$ & 9 & 25 & $\begin{array}{l}\text { Acute renal } \\
\text { failure } 1974 \\
\text { Sickle cell trait }\end{array}$ \\
\hline 2 & $\begin{array}{l}\text { Irreg- } \\
\text { ular }\end{array}$ & $\begin{array}{l}\text { Irreg- } \\
\text { ular }\end{array}$ & 0 & Linear & + & 0 & 0 & 94 & $2 \cdot 45$ & 0.8 & 9 & 12 & Nil \\
\hline 2 & 0 & 0 & $\begin{array}{l}\text { Irreg- } \\
\text { ular }\end{array}$ & $\begin{array}{l}\text { Irreg- } \\
\text { ular }\end{array}$ & 0 & 0 & 0 & 110 & $2 \cdot 46$ & $1 \cdot 2$ & 9 & 18 & Hypertension \\
\hline 1 & $\begin{array}{l}\text { Irreg- } \\
\text { ular }\end{array}$ & 0 & 0 & 0 & 0 & 0 & 0 & 56 & $2 \cdot 62$ & 0.9 & - & 20 & Nil \\
\hline
\end{tabular}


Table 3 Comparison of 2 groups of patients with gout

\begin{tabular}{|c|c|c|c|c|c|c|}
\hline & \multirow[t]{2}{*}{ Number } & \multirow[t]{2}{*}{ Age (years) } & \multirow{2}{*}{$\begin{array}{l}\text { Duration of } \\
\text { gout (years) }\end{array}$} & \multirow{2}{*}{$\begin{array}{l}\text { Osteoarthrosis } \\
\text { of the knees } \\
\text { grade } 2\end{array}$} & \multirow[t]{2}{*}{ Tophi } & \multirow{2}{*}{$\begin{array}{l}\text { Renal impairment } \\
\text { Creatinine clearance } \\
<60 \text { ml/min } \\
\text { Creatinine }>140 \text { umol } /\end{array}$} \\
\hline & & & & & & \\
\hline \multirow{2}{*}{$\begin{array}{l}\text { Gout without } \\
\text { chondrocalcinosis } \\
\text { Gout with chondro- } \\
\text { calcinosis } \\
\text { Significance }\end{array}$} & 130 & $54 \cdot 7 \pm 13 \cdot 0$ & $12 \cdot 9 \pm 9 \cdot 8$ & 10 & 21 & 11 \\
\hline & 8 & $\begin{array}{l}61 \cdot 1 \pm 10 \cdot 3 \\
\mathrm{NS}\end{array}$ & $\begin{array}{l}20 \cdot 5 \pm 14.2 \\
P<0.05\end{array}$ & $\stackrel{4}{P}<0.02$ & $\stackrel{2}{\mathrm{NS}}$ & $\stackrel{2}{\mathrm{NS}}$ \\
\hline
\end{tabular}

calcification, though definite, tended to be rather faint. Evidence of chondrocalcinosis in the symphysis pubis or hips was seen in 4 of the patients all of them with linear deposits in the knees. Three patients showed radiological evidence of calcium deposition in the wrists, mainly in relation to the triangular ligament. Six of the 8 patients thus showed evidence of chrondrocalcinosis in sites additional to the knees.

Tophaceous deposits were present in two of the 8 patients and were not extensive.

Urinary urate on a low-purine diet was normal or only slightly raised in all of the patients. Some evidence of renal functional impairment (creatinine clearance less than $60 \mathrm{ml} / \mathrm{min}$ or plasma creatinine $>140 \mu \mathrm{mol} / \mathrm{l}$ ) was present in two of the 8 patients, although 1 other (a woman with sickle cell trait) had had an episode of acute renal failure previously. There was no evidence of other metabolic disorders commonly associated with chondrocalcinosis.

Comparison of the patients with chondrocalcinosis with the rest of the gout patients (Table 3) shows no significant difference in age, prevalence of tophi, or prevalence of renal impairment. The duration of gout appeared to be longer in the patients with chondrocalcinosis, and osteoarthrosis of the knees was relatively more common.

No cases of avascular necrosis of the femoral head were found in any of the gout patients or control subjects.

\section{Discussion}

These results appear to confirm some form of association between gout and chondrocalcinosis (Dodds and Steinbach, 1966; Alarcon-Segovia and Garza, 1969; Martel et al., 1970). The prevalence of chondrocalcinosis in the gouty population- $5.8 \%$-is close to that of $5 \%$ reported by Good and Rapp (1967) in 43 patients with gout of the same mean age. That study also included patients with rheumatoid arthritis, $8 \%$ of whom showed chondrocalcinosis, and it was concluded that the prevalence in both conditions was no higher than might be expected by chance alone. However Dodds and
Steinbach (1966), in an uncontrolled study, reported a considerably higher prevalence of chondrocalcinosis (32\%) in 31 patients with gout: the deposits were faint, and linear and punctate calcifications were not detected.

Perhaps rather surprisingly, no cases of chondrocalcinosis were found in 142 age-matched controls. The reported prevalence in older subjects ranges from $2 \cdot 2$ to $27 \cdot 6 \%$ (McCarty, 1976). The frequency of chondrocalcinosis increases with age (Bocher et al., 1965; Ellman and Levin, 1975; Nuki et al., 1978). Special radiographic techniques will detect early and subtle calcification which would be missed on standard radiographs (Parlee et al., 1967; Genant, 1976).

The mean age of the 142 control subjects$54.9 \pm 13.4$ years-was lower than that of the elderly subjects, in whom relatively high prevalences of chondrocalcinosis have been reported, and this difference probably accounts for the lack of calcification in these subjects. Since only routine radiographs were used, early calcification may have been missed, but this of course applied also to the gout patients. There is certainly no reason to believe that selection of controls was unrepresentative of the population as a whole.

The cause of episodes of acute synovitis of the knee which had occurred in 6 of the 8 patients with gout and chondrocalcinosis remains largely unknown, since joint fluid had been examined in only 2 of them, urate crystals being found in one and no crystals in the other. The linear pattern of calcification seen in 6 patients is strongly suggestive of calcium pyrophosphate deposition (McCarty et al., 1966). The irregular pattern of calcification seen in 3 patients could well be due to other types of calcium deposits (Dieppe et al., 1976). Calcification was not restricted to the knee joint, being found elsewhere (hips," pubic symphysis, and wrists) in 6 of the 8 patients.

There was no overall difference in the prevalence of radiological osteoarthrosis between the gouty and control groups, but most of the patients with chondrocalcinosis showed evidence of osteoarthrosis of the knees. This may have been secondary to 
chondrocalcinosis (Hamilton, 1976; Zitnan and Sitaj, 1976; Resnick et al., 1977). An association with tophaceous deposition and renal impairment, claimed by other investigators (Dodds and Steinbach, 1966; Alarcon-Segovia and Garza, 1969) is not supported by the present study. Nor has any evidence been found of an association with other metabolic disorders.

It thus appears likely that there is some association between calcium pyrophosphate deposition and urate gouty arthritis. The nature of this association remains obscure, but it suggests some underlying common predisposition to crystal deposition in connective tissue (Reginato et al., 1974; Bjelle, 1972; Katz, 1975); or perhaps urate crystals may act as nucleating substances leading to deposition of pyrophosphate or apatite.

The failure to detect evidence of avascular necrosis of the femoral head in any of the gout patients (together with the fact that we have never to our knowledge encountered such an association in a larger experience of several hundred patients with gout) is at variance with the findings of Serre $e t$ al. (1963), and probably reflects the heterogeneity of hyperuricaemia and gout in different populations and communities, with different influences of such factors as, for example, hyperlipidaemia and alcohol, which may perhaps predispose to osteonecrosis.

\section{References}

Alarcon-Segovia, D., and Garza, R. (1969). Articular chondrocalcinosis secondary to gout: relationship to chronic renal failure. Arthritis and Rheumatism, 12, 276.

Bjelle, A. O. (1972). Morphological study of articular cartilage in pyrophosphate arthropathy. Annals of the Rheumatic Diseases, 31, 449-456.

Bjelle, A., and Sunden, G. (1974). Pyrophosphate arthropathy: a clinical study of fifty cases. Journal of Bone and Joint Surgery, 56B, 246-255.

Bocher, J., Mankin, H. J., Berk, P. N., and Rodan, G. P. (1965). Prevalence of calcified meniscal cartilage in elderly persons. New England Journal of Medicine, 272, 1093-1097.

Dieppe, P. A., Huskisson, E. C., Crocker, P., and Willoughby, D. A. (1976). Apatite deposition disease. A new arthropathy. Lancet, 1, 266-270.

Dodds, W. J., and Steinbach, H. L. (1966). Gout associated with calcification of cartilage. New England Journal of Medicine, 275, 745-749.

Dymock, I. W., Hamilton, E. B. D., Laws, J. W., and Williams, R. (1970). Arthropathy of haemochromatosis. Annals of the Rheumatic Diseases, 29, 469-476.

Ellman, M. H., and Levin, B. (1975). Chondrocalcinosis in elderly persons. Arthritis and Rheumatism, 18, 43-47.
Genant, H. J. (1976). Roentgenographic aspects of calcium pyrophosphate dihydrate crystal deposition disease (pseudogout). Arthritis and Rheumatism, 19, 307-328.

Good, A. E., and Rapp, R. (1967). Chondronicalcosis of the knee with gout and rheumatoid arthritis. New England Journal of Medicine, 277, 286-290.

Hamilton, E. B. D. (1976). Diseases associated with C.P.P.D. deposition disease. Arthritis and Rheumatism, 19, 353-357.

Kellgren, J. H., and Lawrence, J. S. (1957). Radiological assessment of osteo-arthrosis. Annals of the Rheumatic Diseases, 16, 494-502.

Katz, W. A. (1975). Deposition of urate crystals in gout. Altered connective tissue metabolism. Arthritis and Rheumatism, 18, 751-756.

Martel, W., Champion, C. K., Thompson, G. R., and Carter, T. L. (1970). Roentgenologically distinctive arthropathy in some patients with the pseudogout syndrome. American Journal of Roentgenology, Radium Therapy and Nuclear Medicine, 109, 587-605.

McCarty, D. J., Hogan, J. M., Gatter, R. A., and Grossman, M. (1966). Studies on pathological calcification in human cartilage. I. Prevalence and types of crystal deposits in the menisci of two hundred fifteen cadavera. Journal of Bone and Joint Surgery, 48A, 309-325.

McCarty, D. J. (1972). Pseudogout; articular chondrocalcinosis calcium pyrophosphate crystal deposition disease. In Arthritis and Allied Conditions, 8th edn., pp. 1140-1160. Edited by I. L. Hollander and D. J. McCarty. Lea and Febiger: Philadelphia.

McCarty, D. J. (1976). Calcium pyrophosphate dihydrate crystal deposition disease-1975. Arthritis and Rheumatism, 19, 275-285.

McCollum, D. E., Clippinger, F. W., O'Neil, M. T., and Mathews, R. R. (1967). Aseptic necrosis of the femoral head. Associated diseases and evaluation of treatment. Journal of Bone and Joint Surgery, 49A, 1019-1021.

Nuki, G., Pritchard, H. H., Henderson, W. J., and Lust, G. (1978). European Journal of Rheumatology and Inflammation, 1, 105.

Parlee, D. E., Freundlich, I. M., and McCarthy, D. J. (1967). A comparative study of roentgenographic techniques for detection of calcium pyrophosphate dihydrate deposits (pseudogout) in human cartilage. American Journal of Roentgenology, Radium Therapy and Nuclear Medicine, 99, 688-694.

Reginato, A. J., Schumacher, H. R., and Martinez, V. A. (1974). The articular cartilage in familial chondrocalcinosis. Light and electron microscopic study. Arthritis and Rheumatism, 17, 977-992.

Resnick, D., Niwayama, G., Goergen, T. G., Utsinger, P. D., Shapiro, R. F., Haselwood, D. H., and Wiesner, K. B. (1977). Clinical, radiographic and pathologic abnormalities in calcium pryophosphate dihydrate deposition disease (CPPD): pseudogout. Radiology, 122, 1-15.

Rotes Querol, A. J., and Munoz Gomez, G. J. (1965). Gota en la ladera. Revista espanola do reumatismo y enfermedades osteoarticulares, 11, 89-98.

Serre, H., Simone, L., and Claustre, J. (1963). A propos de l'atteinte des hanches au cours de goutte. Revue du Rheumatisme, 30, 741-746.

Zitnan, D., and Sitaj, S. (1976). Natural course of articular chondrocalcinosis Arthritis and Rheumatism, 19, 363-390. 